\title{
ANALISIS HUBUNGAN EFIKASI DIRI DENGAN KINERJA KARYAWAN PADA PT METRAPLASA
}

\author{
Hani Ratnasari dan Nancy Yusnita \\ Fakultas Ekonomi Universitas Pakuan \\ Email: haniratnasari19@gmail.com dan nancyariadiningrat7@gmail.com
}

ARTICLE INFO
Article History:

Received 16 July 2018

Revised 15 August 2018

Accepted 31 August 2018

JEL Classification:

E24, J80, J81

Kata kunci:

Efikasi diri, dan

Kinerja karyawan

\begin{abstract}
Abstrak
Aspek sumber daya manusia menjadi sangat penting dalam pencapaian tujuan organisasi. Karyawan yang berkinerja tinggi telah menjadi topik bahasan dalam banyak tulisan ilmiah bidang sumber daya manusia. Banyak factor yang menyebabkan seorang karyawan mampu berkinerja optimal, salah saatunya adalah efikasi diri, yaitu keyakinan seseorang bahwa ia mampu menyelasikan tugas yang diberikan dengan kondisi tertetu.

Tujuan dari penelitian ini adalah untuk mengetahui tingkat efikasi diri pada karyawan PT Metraplasa, kinerja karyawan PT Metraplasa, dan hubungan efikasi diri dengan kinerja karyawan pada PT Metraplasa. Penelitian ini difokuskan kepada karyawan PT Metraplasa yang bergerak dibidang retail online atau e-commerce. Pengumpulan data dalam penelitian ini dilakukan melalui wawancara dan kuesioner yang dibagikan pada 141 responden. Hasil penelitian menunjukkan bahwa tingkat efikasi diri dan kinerja karyawan PT Metraplasa sudah baik. Selain itu, terdapat hubungan nyata yang signifikan antara efikasi diri dengan kinerja karyawan. Hal ini mengindikasikan bahwa semakin tinggi efikasi diri yang dimiliki oleh karyawan maka semakin tinggi pula tingkat kinerja karyawan yang ada dalam perusahaan.
\end{abstract}

\section{PENDAHULUAN}

Efikasi Diri atau Self-efficacy menentukan bagaimana seseorang merasakan sesuatu, berfikir, memotivasi diri mereka sendiri dan juga perilaku mereka. Individu dengan self-efficacy yang tinggi bersikap positif, berorientasi kesuksesan dan berorientasi tujuan. Self-efficacy karyawan tinggi membuat karyawan akan berusaha menyelesaikan permasalahan kerja dan meningkatkan kerja secara maksimal sesuai dengan kemampuan yang dimiliki karyawan (Riani dan Farida 2008).
Semakin tingginya efikasi diri yang ada pada karyawan, maka semakin meningkatnya kinerja karyawan. Efikasi diri yang tinggi dapat ditunjukan dengan adanya pekerjaan yang cepat terselesaikan, kehadiran dan keloyalan karyawan terhadap perusahaan. Tingkat keluar masuk karyawan yang tinggi merupakan salah satu dari penyebab kinerja karyawan yang menurun sehingga efikasi diri karyawan rendah.

Penelitian ini difokuskan kepada karyawan PT Metraplasa yang bergerak dibidang retail online atau e-commerce. 
Perusahaan ini beralamat di Jalan MT Haryono kav 58-60, Pancoran Jakarta Selatan dan mempunyai dua belas departemen atau posisi.

Dalam era globalisasi ini, perusahaan $e$ commerce merupakan perusahaan yang mempunyai sumber daya manusia (SDM) yang unggul dan berdaya saing. Sumber daya manusia mempunyai peran sangat penting dalam pengelolaan bisnis ritel karena membutuhkan persiapan dalam arti SDM yang memiliki pengetahuan ketrampilan, baik soft skill maupun hard skill, dalam hal manajerial perusahaan ritel sekaligus kepekaan dalam melihat peluang agar dapat memiliki kompetensi untuk bertahan dalam bisnis retail. Dari hasil pra survey peneliti, selfefficacy sebagai topik baru juga diyakini mempengaruhi kinerja karyawan.

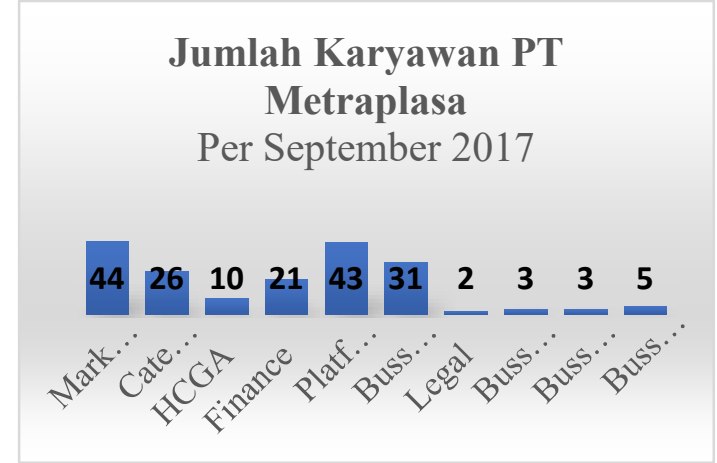

Sumber: HR PT Metraplasa (2017)

Gambar 1. Jumlah karyawan bulan September

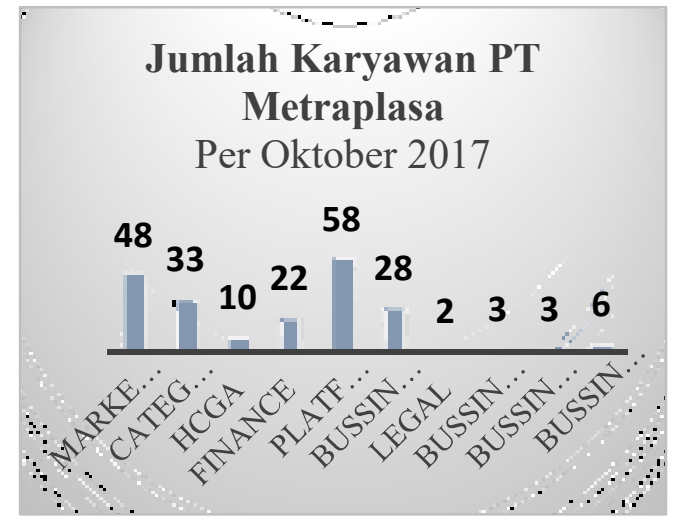

Sumber: HR PT Metraplasa (2017)

Gambar 2. Jumlah karyawan bulan Oktober

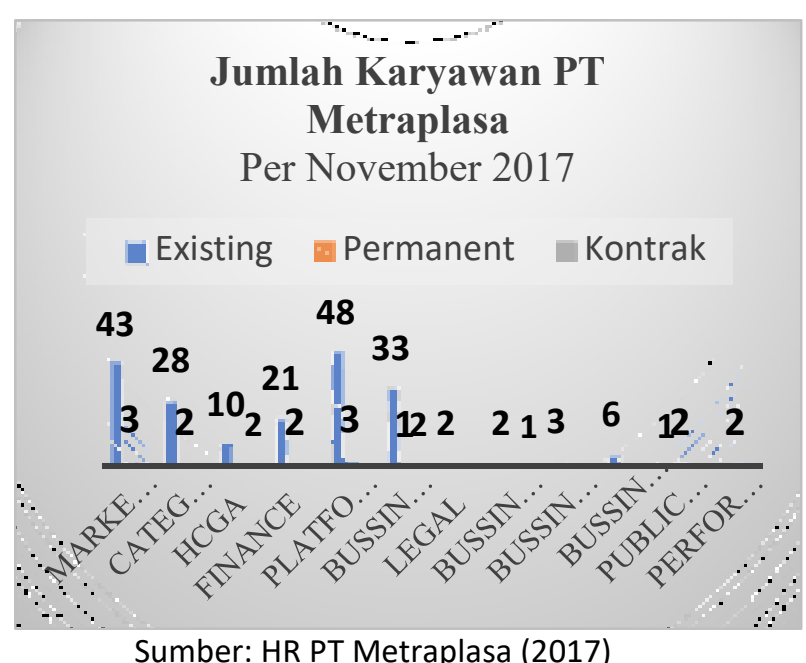

Sumber: HR PT Metraplasa (2017)

Gambar 3. Jumlah karyawan bulan November

Dari ketiga grafik di atas dapat dilihat bahwa jumlah karyawan PT Metraplasa meningkat dari bulan september hingga bulan november dari 188 menjadi 217 orang karyawan yang terdapat di 12 bagian atau departemen yaitu HCGA, Marketing, Platform Development, Bussines Operation, Category Management, Finance, Legal, Performance Management, Public Relation, Bussines Analyst, Bussines IT \& Service, dan Bussines IT \& Infrastructure. Pada bulan November terdapat penambahan bagian yaitu bagian Performance Management dan Public Relation. Adanya penambahan posisi ini mengakibatkan penambahan karyawan dengan tugas dan tanggung jawab yang baru di perusahaan tersebut sehingga pembagian kerja sebelumnya tiap departemen belum merata.

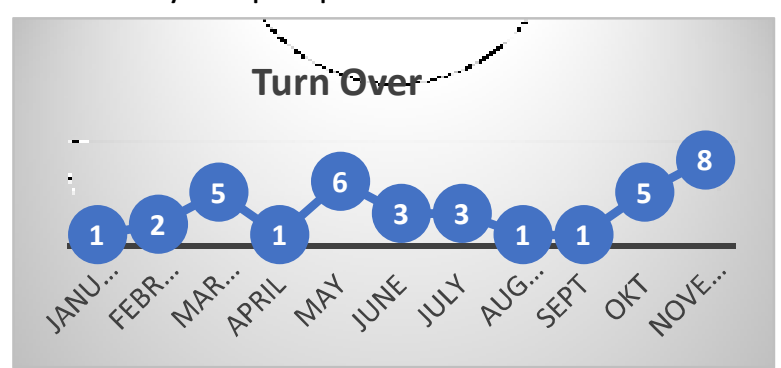

Sumber: HR PT Metraplasa (2017)

Gambar 4. Grafik Turn Over karyawan Metraplasa 
Berdasarkan grafik diatas menunjukkan tingginya angka turn over karyawan dalam kurun waktu sebelas bulan. Semakin tingginya turn over karyawan akibat dari rendahnya efikasi tiap karyawan menyebabkan kinerja karyawan menjadi menurun. Semakin tinggi efikasi karyawan maka semakin meningkat kinerja karyawan tersebut.

Tabel 1. Penilaian Kinerja Karyawan PT Metraplasa Tahun 2017

\begin{tabular}{|c|c|c|c|c|}
\hline \multirow[b]{2}{*}{ Nilai } & \multicolumn{2}{|c|}{2016} & \multicolumn{2}{|c|}{2017} \\
\hline & Jumlah & Presentase & Jumlah & Presentase \\
\hline $\begin{array}{c}\text { Sangat } \\
\text { Baik }\end{array}$ & 84 & $47 \%$ & 63 & $29 \%$ \\
\hline Baik & 14 & $8 \%$ & 30 & $13 \%$ \\
\hline Cukup & 20 & $12 \%$ & 47 & $22 \%$ \\
\hline $\begin{array}{c}\text { Kurang } \\
\text { Baik }\end{array}$ & 52 & $33 \%$ & 77 & $36 \%$ \\
\hline Jumlah & 170 & $100 \%$ & 217 & $100 \%$ \\
\hline
\end{tabular}

Standar Kinerja yang ada pada PT Metraplasa ialah sebagai berikut :

$\begin{array}{ll}\text { Sangat Baik } & =>80 \\ \text { Baik } & =71-80 \\ \text { Cukup } & =61-70 \\ \text { Kurang Baik } & =0-60\end{array}$

Berdasarkan penilaian kinerja di atas dengan beberapa kriteria aspek penilaian diantaranya Tanggung Jawab, Insiatif, Kerjasama, Etika, Disiplin, pengetahuan mengenai pekerjaan, kualitas pekerjaan, kecepatan kerja, kerapihan, kemampuan merencanakan, kemampuan delegasi, dan komitmen pada tugas menunjukkan bahwa kinerja karyawan PT Metraplasa dari tahun 2016-2017 dinilai Kurang Baik. Hal ini terlihat dimana selama 11 bulan angka turn over atau keluar masuknya karyawan PT Metraplasa cukup tinggi sehingga dapat mempengaruhi hasil pekerjaan secara kuantitas dan kualitas yang dihasilkan oleh karyawan karena ketidakmampuan dalam menyelesaikan pekerjaan tersebut. Ketidakmampuan ini terdapat dalam individu karyawan yang berkaitan dengan efikasi diri atau self-efficacy karyawan.

Dalam Pra survey penelitian, Peneliti melakukan penyebaran kuesioner kepada tiga puluh orang karyawan dengan beberapa bagian yang berbeda mengenai efikasi diri atau self-efficacy untuk mengetahui bagaimana sebenarnya efikasi diri yang ada pada karyawan.

Tabel 2. Hasil Kuesioner Pra Survey Karyawan PT Metraplasa

\begin{tabular}{|c|c|c|c|c|c|}
\hline \multirow{2}{*}{ No } & \multirow[t]{2}{*}{ Pernyataan } & \multicolumn{2}{|c|}{ Jawaban } & \multirow{2}{*}{$\begin{array}{l}\text { Jumlah } \\
\text { Pegawai }\end{array}$} & \multirow{2}{*}{$\begin{array}{l}\begin{array}{l}\text { Target } \\
(\%)\end{array} \\
100 \\
\end{array}$} \\
\hline & & Ya & Tidak & & \\
\hline 1 & Motivasi Kerja & 20 & 10 & 30 & 100 \\
\hline 2 & Iklim Organisasi & 10 & 20 & 30 & 100 \\
\hline 3 & Stress Kerja & 15 & 15 & 30 & 100 \\
\hline 4 & Kepemimpinan & 17 & 13 & 30 & 100 \\
\hline 5 & Efikasi Diri & 20 & 10 & 30 & 100 \\
\hline 6 & $\begin{array}{l}\text { Budaya } \\
\text { Organisasi }\end{array}$ & 11 & 19 & 30 & 100 \\
\hline 7 & Komitmen & 16 & 14 & 30 & 100 \\
\hline
\end{tabular}

Sumber: Data Primer diolah 2018 
Berdasarkan tabel hasil kuesioner pra survey diketahui bahwa motivasi kerja dan efikasi diri merupakan hal yang menjadi faktor menurunnya kinerja karyawan. Motivasi kerja dan efikasi diri adalah hal yang terdapat dalam diri karyawan. Karyawan yang memilih motivasi kerja dan efikasi diri menyatakan bahwa mereka merasa kurang termotivasi dalam bekerja sehingga kurang yakinnya karyawan dalam mengerjakan setiap pekerjaan yang ada. Motivasi merupakan bagian dari Efikasi diri karyawan. Maka dalam pra kuesioner ini yang dapat menurunkan kinerja karyawan PT Metraplasa adalah motivasi kerja dan efikasi diri. Akan tetapi, dalam pra kuesioner ini efikasi diri menjadi topik baru dalam perusahaan.

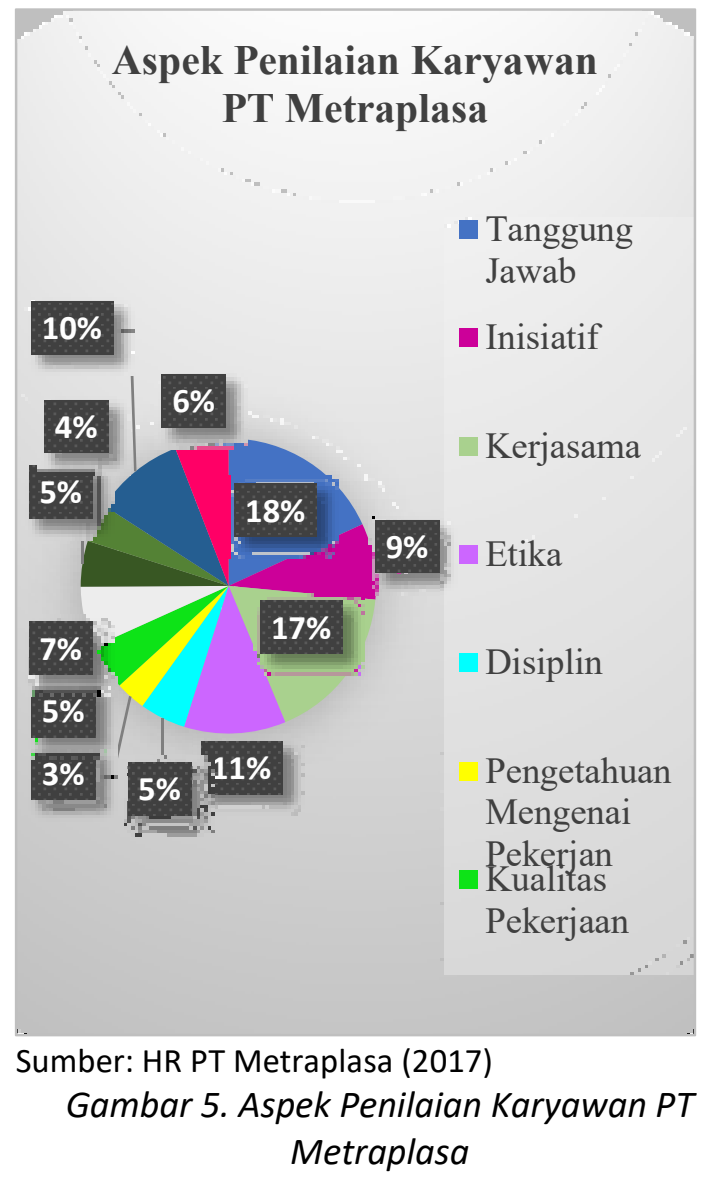

Adapun Efikasi ini ditunjukkan dengan aspek penilaian kinerja. Dalam Diagram di atas menunjukkan bahwa Efikasi diri atau keyakinan dalam diri karyawan PT Metraplasa yang tergambar dari kurangnya aspek kecakapan atau pengetahuan dalam mengerjakan tugas, Kualitas pekerjaan yang dihasilkan, Kemampuan Merencanakan pekerjaan dan Komitmen pada tugas yang dinilai rendah dengan persentase $3 \%$ sampai $7 \%$. Hal ini dikarenakan adanya pembagian pekerjaan yang belum merata dan ketidakyakinan dalam menghadapi permasalahan dalam menyelesaikan pekerjaan dalam diri karyawan sehingga karyawan merasa kurang yakin dapat menyelesaikan pekerjaannya dan kualitas atau kuantitas pekerjaan yang dihasilkannya menjadi kurang baik. Data-data di atas menujukkan masih rendahnya kinerja karyawan PT Metraplasa, tujuan dari penelitian ini adalah meningkatkan kinerja karyawan yang dilakukan melalui peningkatan efikasi diri karyawan.

\section{LANDASAN TEORI \\ Manajemen Sumber Daya Manusia}

Manajemen sumber daya manusia (MSDM) menurut Hasibuan (2014) adalah ilmu dan seni yang mengatur hubungan dan peranan tenaga kerja agar efektif dan efisien membantu terwujudnya tujuan perusahaan, karyawan, dan masyarakat. MSDM merupakan salah satu aspek penting dalam sebuah organisasi. Pada umumnya, MSDM untuk memeperoleh tingkat perkembangan karyawan yang setinggi-tingginya, hubungan kerja yang serasi di antara karyawan, dan penyatupaduan sumber daya manusia secara efektif atau tujuan efisiensi, dan kerja sama sehingga diharapkan akan meningkatkan produktivitas kerja. Lebih lanjut, menurut Yani (2012) fungsi MSDM sebagai perencanaan, pengadaan, pengembangan diri, kompensasi, pengintegrasian, dan pemeliharaan.

\section{Efikasi Diri}

Self-efficacy atau efikasi diri didasarkan pada kerangka teori besar yaitu teori cognitive social. Bandura (2009) menggunakan istilah 
self-efficacy mengacu pada keyakinan (beliefs) tentang kemampuan seseorang untuk mengorganisasikan dan melaksanakan tindakan untuk pencapaian hasil. Dengan kata lain, self-efficacy adalah keyakinan peniliaian diri berkenaan dengan kompetensi seseorang untuk sukses dalam tugas-tugasnya. Menurut Bandura keyakinan self-efficacy merupakan faktor kunci sumber tindakan manusia (human egency), "apa yang orang pikirkan, percaya, dan rasakan mempengaruhi bagaimana mereka bertindak.

Menurut teori kognitif sosial Bandura, keyakinan self-efficacy mempengaruhi pilihan orang dalam membuat dan menjalankan tindakan yang mereka kejar. Individu cenderung berkonsentrasi dalam tugas-tugas yang mereka rasakan mampu dan percaya dapat menyelesaikannya serta menghindari tugas-tugas yang tidak dapat mereka kerjakan. Keyakinan efficacy juga membantu menentukan sejauh mana usaha yang akan dikerahkan orang dalam suatu aktivitas, seberapa lama mereka akan gigih ketika menghadapi rintangan, dan seberapa ulet mereka akan menghadapi situasi yang tidak cocok.

\section{Kinerja Karyawan}

Kinerja yang baik jika dilakukan maka akan menghasilkan suatu hasil yang memuaskan perusahaan dan karyawan itu sendiri, tetapi kinerja yang buruk akan membawa dampak yang sangat tidak baik bagi perusahaan, dapat menjatuhkan perusahaan dan menggulingkan perusahaan sehingga tujuan untuk kemajuan tidak bisa tercapai. Kinerja pada dasarnya yaitu apa yang dilakukan atau tidak dilakukan karyawan. Hasibuan (2014) mengemukakan kinerja (prestasi kerja) adalah suatu hasil kerja yang dicapai seseorang dalam melaksanakan tugas-tugas yang dibebankan kepadanya yang didasarkan atas kecakapan, pengalaman dan kesungguhan serta waktu.
Menurut Robbins (2015), indikator untuk mengukur kinerja karyawan secara individu ada enam indikator, yaitu:

1. Kualitas. Kualitas kerja diukur dari persepsi karyawan terhadap kualitas pekerjaan yang dihasilkan serta kesempurnaan tugas terhadap keterampilan dan kemampuan karyawan.

2. Kuantitas. Merupakan jumlah yang dihasilkan dinyatakan dalam istilah seperti jumlah unit, jumlah siklus aktivitas yang diselesaikan.

3. Ketepatan waktu. Merupakan tingkat aktivitas diselesaikan pada awal waktu yang dinyatakan, dilihat dari sudut koordinasi dengan hasil output serta memaksimalkan waktu yang tersedia untuk aktivitas lain.

4. Efektivitas. Merupakan tingkat penggunaan sumber daya organisasi (tenaga, uang, teknologi, bahan baku) dimaksimalkan dengan maksud menaikkan hasil dari setiap unit dalam penggunaan sumber daya.

5. Kemandirian. Merupakan tingkat seorang karyawan yang nantinya akan dapat menjalankan fungsi kerjanya Komitmen kerja. Merupakan suatu tingkat dimana karyawan mempunyai komitmen kerja dengan instansi dan tanggung jawab karyawan terhadap kantor.

\section{KERANGKA PEMIKIRAN DAN HIPOTESIS}

Efikasi memegang peran yang sangat penting dalam kehidupan sehari-hari seseorang akan mampu menggunakan potensi dirinya secara optimal apabila efikasi diri mendukungnya. Selain itu, self-efficacy atau efikasi diri berperan penting dalam organisasi terkait dengan kinerja (Job Performance). Individu dengan self-efficacy yang tinggi, akan menunjukkan komitmen dan motivasi diri untuk menampilkan kinerja yang diharapkan.

Self-efficacy adalah keyakinan seseorang akan kemampuan atau kompetensinya atas kinerja tugas yang diberikan, mencapai tujuan atau mengatasi sebuah hambatan. Individu yang memiliki efikasi tinggi maka ia akan 
merasa yakin dan mampu dalam mengerjakan segala tugas dan mengatasi segala hambatan yang ada.

Seperti disebutkan di atas, self-efficacy atau efikasi diri berkaitan dengan aspek objektif seseorang dalam organisasi yaitu kinerjanya. Kepercayaan terhadap kemampuan diri, keyakinan terhadap keberhasilan yang selalu dicapai membuat seseorang bekerja lebih giat dan selalu menghasilkan yang terbaik.

Kinerja adalah suatu hasil kerja yang dicapai oleh seseorang dalam melaksanakan tugas sesuai tanggung jawabnya dengan standar hasil kerja, target atau sasaran yang telah ditentukan dan disepakati bersama untuk mencapai tujuan organisasi atau perusahaan.

Individu cenderung berkonsentrasi dalam tugas-tugas yang mereka rasakan mampu dan percaya dapat menyelesaikannya serta menghindari tugas-tugas yang tidak dapat mereka kerjakan. Keyakinan efficacy juga membantu menentukan sejauh mana usaha yang akan dikerahkan orang dalam suatu aktivitas, seberapa lama mereka akan gigih ketika menghadapi rintangan, dan seberapa ulet mereka akan menghadapi situasi yang tidak cocok.

Kinerja karyawan memiliki hubungan dengan efikasi diri atau self-efficacy, karena Keyakinan akan kemampuan yang dimiliki oleh tiap individu ini akan mencapai hasil pekerjaan atau kinerja yang baik ditunjukan dengan kuantitas dan kualitasnya. Dan Sebaliknya, Apabila Efikasi diri yang dimiliki cenderung rendah maka akan mengakibatkan ketidakberhasilan dalam melaksanakan atau menyelesaikan pekerjaan yang diberikan kepadanya.

Dengan efikasi diri atau self-efficacy yang kuat diindikasi akan membuat kinerja karyawan meningkat dengan memberikan hasil kerja yang memuaskan dan membantu dalam pencapaian tujuan organisasi atau perusahaan yang diinginkan.

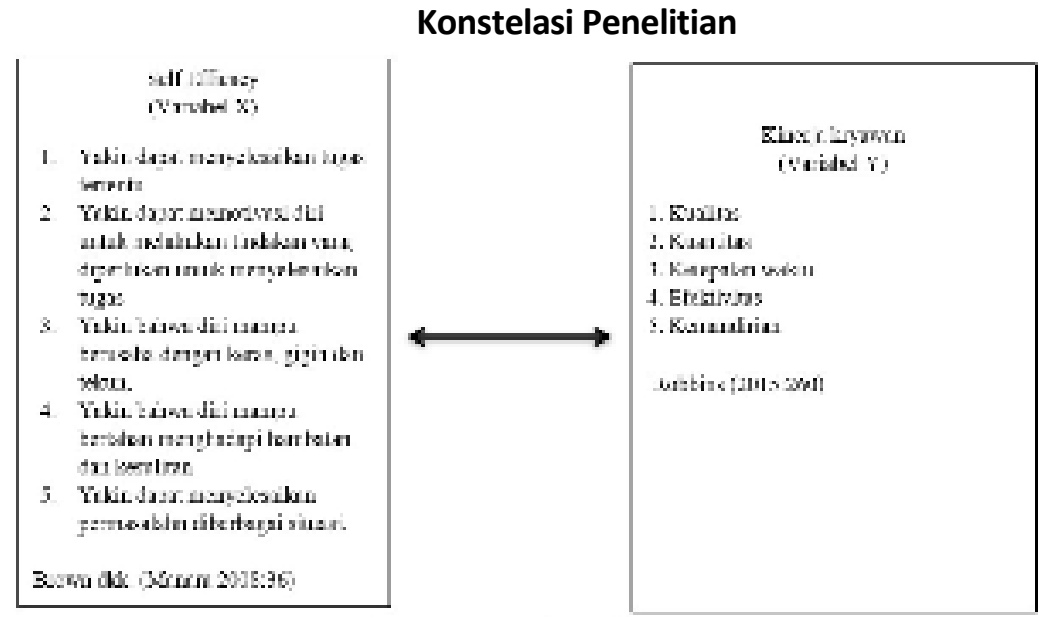

Berdasarkan uraian di atas maka dapat dirumuskan hipotesis bahwa diduga terdapat hubungan yang positif antara self efficacy dengan kinerja karyawan PT Metraplasa.

\section{METODE PENELITIAN}

\section{Jenis Penelitian}

Jenis penelitian yang digunakan dalam penelitian ini adalah Deskriptif Kuantitatif Korelasional dimana penelitian ini bertujuan untuk menentukan ada tidaknya hubungan ke arah positif atau negatif dan seberapa jauh hubungan yang ada antara dua variabel atau lebih mengenai hubungan efikasi diri dengan kinerja karyawan.

\section{Objek, Unit Analisis, dan Lokasi Penelitian}

Objek penelitian yang penulis gunakan dalam penelitian ini adalah Efikasi Diri sebagai variabel independen $(\mathrm{X})$ dan Kinerja Karyawan 
sebagai variabel dependen (Y) PT Metraplasa. Dalam penelitian ini, unit analisis dalam penelitian ini adalah karyawan PT Metraplasa berjumlah 141 orang karyawan, Lokasi penelitian di Jalan MT Haryono kav 58-59, Pancoran Jakarta Selatan.

\section{Teknik Pengambilan Sampel}

Populasi diartikan sebagai jumlah kesuluruhan semua anggota yang diteliti, sedangkan sampel merupakan bagian yang diambil dari populasi. Dalam penelitian ini yang menjadi populasi adalah karyawan PT Metraplasa yang berjumlah 217 orang yang tersebar di 12 Bagian HCGA, Marketing, Public Relation, Platform Development, Bussines Operation, Category Management, Finance, Legal, Performance Management, Bussines Analyst, Bussines IT \& Service, dan Bussines IT \& Infrastructure. Karena jumlah populasi karyawan yang diteliti terlalu luas, tidak memungkinkan untuk meneliti semua jumlah populasi, maka diambillah sampel yang merupakan bagian dari populasi tersebut.

Untuk menentukan berapa minimal sampel yang dibutuhkan jika ukuran populasi
(N) diketahui, dapat digunakan metode slovin yaitu:

Rumus: $n=\frac{N}{1+N e^{2}}$

Dimana:

$\mathrm{n}=$ Ukuran sampel

$\mathrm{N}=$ Ukuran populasi

$\mathrm{e}=$ Kelonggaran ketidaktelitian karena kesalahan pengambilan sampel yang dapat ditolerir yaitu sebesar $5 \%$,

Dari jumlah seluruh populasi sebanyak 217 orang maka pengambilan sampel menurut rumus ini adalah:

$n=\frac{N}{1+N e^{2}}$

$n=\frac{217}{1+(217)(0,05)^{2}}$

$\mathrm{n}=140,6807$

Jadi sampel yang dibutuhkan dalam penelitian ini adalah sebanyak 140,6807 dibulatkan menjadi 141 orang. Untuk mengetahui ukuran alokasi pada masingmasing bagian digunakan alokasi sampel proporsional yang dapat ditentukan dengan menggunakan perhitungan sebagai berikut:

$\frac{\text { Jumlah Karyawan (per bagian) }}{\text { Jumlah total Karyawan }} \times$ Sampel yang dibutuhkan

Berdasarkan perhitungan diatas, dapat diperoleh jumlah responden setiap bagian yang terpilih, yaitu HCGA (6 sampel), Marketing (31 sampel), Public Relation (2 sampel), Platform Development (37 sampel), Bussines Operation (18 sampel), Category Management (23 sampel), Finance (14 sampel), Legal (2 sampel), Performance Management (2 sampel), Bussines Analyst (2 sampel), Bussines IT \& Service (2 sampel), dan Bussines IT \& Infrastructure (4 sampel).

\section{Metode Pengumpulan Data}

Pengumpulan data menggunakan data primer, yaitu penelitian yang dilakukan dengan cara mengumpulkan data secara langsung terhadap objek penelitian dan mengumpulkan informasi yang relevan dengan pokok permasalahan dengan cara:

1. Survey

Survey yaitu metode yang digunakan untuk mendapatkan informasi dengan menanyai orang melalui daftar pertanyaan atau kuesioner yang terstruktur yang bertujuan memperoleh informasi seperti preferensi, sikap, atau, pendapat atau responden yang diungkapkan dalam menjawab pertanyaan. Metode pengumpulan data ini dibagi menjadi dua, yaitu:

a. Wawancara 
Nancy Yusnita: Analisis Hubungan Efikasi...

Wawancara yaitu metode untuk mendapatkan data dengan cara melakukan tanya jawab secara langsung dengan pihak-pihak yang bersangkutan yaitu karyawan PT Metraplasa guna mendapatkan data dan keterangan yang menunjang analisis dalan penelitian.

b. Kuesioner (angket)

Metode pengumpulan data dengan cara menyebarkan daftar pertanyaan yang berkaitan dengan variabel penelitian kepada responden yang dijadikan sebagai sampel penelitian, yaitu karyawan PT Metraplasa sebanyak 141 orang.

Dalam metode pengumpulan data yang dilakukan dengan penyebaran kuesioner ini skala pengukuran yang digunakan yaitu skala likert yang dikembangkan oleh Rensis Likert. Skala ini mengukur tingkat persetujuan atau ketidaksetujuan responden terhadap serangkaian pertanyaan yang mengukur suatu objek, dalam penelitian ini objek yang dimaksud adalah efikasi diri dan kinerja karyawan.

Skor yang digunakan dalam pengukuran dengan skala ini adalah sebagai berikut:

$\begin{array}{ll}\text { Sangat Setuju } & =5 \\ \text { Setuju } & =4 \\ \text { Kurang Setuju } & =3 \\ \text { Tidak Setuju } & =2 \\ \text { Sangat Tidak Setuju } & =1\end{array}$

2. Observasi

Peneliti melakukan suatu pengamatan secara langsung dan mempelajari hal-hal yang berhubungan dengan masalah yang akan diteliti pada perusahaan yaitu efikasi diri dengan kinerja karyawan guna mengetahui permasalahan yang sebenarnya.

\section{Operasionalisasi Variabel}

Operasional setiap variabel harus didefinisikan, hal ini bertujuan untuk menterjemahkan variabel dengan tegas, sehingga menjadi faktor-faktor yang dapat diukurkan.

Variabel yang digunakan dalam penelitian ini adalah efikasi diri sebagai variabel bebas (X) dan kinerja karyawan sebagai variabel terikat (Y). Definisi operasional variabel tersebut adalah:

Tabel 3. Efikasi Diri

\begin{tabular}{|c|c|c|c|}
\hline Variabel & Indikator & Ukuran & Skala \\
\hline \multirow[t]{3}{*}{$\begin{array}{l}\text { Efikasi Diri (Self } \\
\text { Efficacy) } \\
\text { (X) }\end{array}$} & $\begin{array}{l}\text { Yakin dapat } \\
\text { menyelesaikan tugas } \\
\text { tertentu }\end{array}$ & $\begin{array}{l}\text { 1. Perasaan mampu } \\
\text { melakukan pekerjaan. } \\
\text { 2. Tingkat Keyakinan dalam } \\
\text { penyelesaian tugas } \\
\text { 3. Inisiatif dalam } \\
\text { penyelesaian tugas tanpa } \\
\text { menunggu perintah }\end{array}$ & Ordinal \\
\hline & $\begin{array}{lr}\text { Yakin dapat } & \text { memotivasi } \\
\text { diri untuk melakukan } \\
\text { tindakan } & \text { yang } \\
\text { diperlukan } & \text { untuk } \\
\text { menyelesaikan tugas }\end{array}$ & $\begin{array}{l}\text { 1. Motivasi karyawan dalam } \\
\text { menyelesaikan pekerjaan } \\
\text { 2. Memberikan target } \\
\text { penyelesaian pekerjaan }\end{array}$ & Ordinal \\
\hline & $\begin{array}{l}\text { Yakin bahwa diri mampu } \\
\text { berusaha dengan keras, } \\
\text { gigih dan tekun, }\end{array}$ & $\begin{array}{l}\text { 1. Kecekatan dalam } \\
\text { menghadapi pekerjaan } \\
\text { 2. Tingkat kesulitan tugas } \\
\text { yang dikerjakan }\end{array}$ & Ordinal \\
\hline
\end{tabular}




\begin{tabular}{|c|c|c|c|}
\hline & & $\begin{array}{l}\text { 3. Mengandalkan } \\
\text { penyelesaian pekerjaan } \\
\text { sendiri }\end{array}$ & \\
\hline & $\begin{array}{l}\text { Yakin bahwa diri mampu } \\
\text { bertahan menghadapi } \\
\text { hambatan dan kesulitan }\end{array}$ & $\begin{array}{l}\text { 1. Penyesuaian diri dengan } \\
\text { lingkungan kerja } \\
\text { 2. Tingkat pekerjaan yang } \\
\text { terlalu sulit }\end{array}$ & Ordinal \\
\hline & $\begin{array}{l}\text { Yakin dapat } \\
\text { menyelesaikan } \\
\text { permasalahan } \\
\text { diberbagai situasi }\end{array}$ & $\begin{array}{l}\text { 1. Kecermatan Karyawan } \\
\text { dalam penyelesaian } \\
\text { masalah } \\
\text { 2. Sikap Pro Aktif dalam } \\
\text { permasalahan pekerjaan }\end{array}$ & Ordinal \\
\hline
\end{tabular}

Tabel 4. Kinerja Karyawan

\begin{tabular}{|c|c|c|c|}
\hline Variabel & Indikator & Ukuran & Skala \\
\hline \multirow[t]{5}{*}{ Kinerja (Y) } & Kualitas & $\begin{array}{l}\text { 1. Hasil Kerja sesuai dengan } \\
\text { standar yang ditetapkan } \\
\text { 2. Tingkat Ketelitian untuk } \\
\text { menghindari kesalahan } \\
\text { dalam bekerja } \\
\text { 3. Tingkat kemampuan dan } \\
\text { keterampilan yang tinggi }\end{array}$ & Ordinal \\
\hline & Kuantitas & $\begin{array}{l}\text { 1. Kemampuan penyelesaian } \\
\text { Jumlah pekerjaan yang } \\
\text { dapat diselesaikan }\end{array}$ & Ordinal \\
\hline & Ketepatan waktu & $\begin{array}{l}\text { 1. Ketepatan waktu saat } \\
\text { masuk dan pulang kantor } \\
\text { 2. Kesesuaian waktu } \\
\text { penyelesaian dengan } \\
\text { target yang telah } \\
\text { ditetapkan } \\
\text { 3. Pemanfaatan waktu saat } \\
\text { menyelesaikan tugas }\end{array}$ & Ordinal \\
\hline & Efektivitas & $\begin{array}{l}\text { 1. Keterbukaan penerimaan } \\
\text { kritik dari hasil pekerjaan } \\
\text { 2. Pekerjaan dilakukan } \\
\text { dengan cermat } \\
\text { 3. Penggunaan alat bantu } \\
\text { kerja yang mendukung } \\
\text { pekerjaan }\end{array}$ & Ordinal \\
\hline & Kemandirian & $\begin{array}{l}\text { 1. Tingkat seorang karyawan } \\
\text { dalam menjalankan fungsi } \\
\text { kerjanya tanpa meminta } \\
\text { bantuan orang lain. } \\
\text { 2. Kemandirian dalam } \\
\text { bekerja sesuai dengan } \\
\text { identitas diri dan } \\
\text { kemampuan berinisiatif }\end{array}$ & Ordinal \\
\hline
\end{tabular}




\begin{tabular}{l|l|l|l}
\hline & $\begin{array}{l}\text { 3. Bertanggung jawab atas } \\
\text { segala pekerjaan yang } \\
\text { dikerjakan }\end{array}$ & \\
\hline
\end{tabular}

\section{Metode Analisis Uji Validitas}

Uji validitas adalah suatu ukuran yang menunjukan apakah kita benar-benar mengukur apa yang kita pikirkan sedang kita ukur. Metode yang digunakan untuk menguji validitas dalam penelitian ini adalah korelasi Pearson Product Moment.

\section{Uji Reliabilitas}

Reliabilitas menyangkut ketepatan alat ukur. Suatu alat ukur disebut memiliki reliabilitas tinggi atau dapat dipercaya, jika alat ukur itu mantap, dalam artian bahwa alat ukur tersebut stabil, dapat diandalkan (dependability) dan dapat diramalkan (predioctability). Dalam penelitian ini reliabilitas instrument diukur menggunakan rumus cronbach alpha.

\section{Analisis Deskripstif}

Analisis Deskriptif digunakan untuk menganalisis data dengan cara mendeskriptifkan atau menggambarkan data yang telah terkumpul sebagaimana adanya, tanpa bermaksud membuat kesimpulan yang berlaku untuk umum. Untuk mendekriptifkan atau menggambarkan data dengan melakukan kegiatan pengumpulan data, pengelompokkan data, penentuan nilai dan fungsi statistik, serta pembuatan grafik, diagram dan gambar.

\section{Analisis Kuantitatif}

Analisis kuantitatif bertujuan mencari hubungan yang menjelaskan sebab-sebab dalam fakta-fakta sosial yang terukur, menunjukan hubungan variabel serta menganalisa. Penelitian kuantitatif ini dilakukan dengan mengumpulkan data dan hasil analisis untuk mendapatkan informasi yang harus disimpulkan.

1. Analisis Korelasi Rank Spearman
Korelasi Rank Spearman digunakan untuk menguji hipotesis antara dua variabel yaitu variabel $X$ (independen) dan variabel $Y$ (dependen). Ukuran yang dipakai untuk mengetahui kuat atau tidaknya hubungan antara $X$ dan $Y$ disebut Koefisien Korelasi $(r)$. Nilai $r$ harus paling sedikit -1 dan paling besar 1 , artinya:

a. Jika nilai $r=+1$ atau mendekati +1 , maka korelasi antara kedua variabel sangat kuat dan positif

b. Jika nilai $r=-1$ atau mendekati -1 , maka korelasi antara kedua variabel sangat kuat dan negatif

c. Jika nilai $r=0$ atau mendekati 0 , maka korelasi antara kedua variabel yang diteliti tidak ada sama sekali atau sangat lemah.

2. Analisis Koefisien Determinasi $\left(r^{2}\right)$ Koefisien determinasi merupakan kuadran koefisien korelasi. Dalam penggunaanya, koefisien determiansi dinyatakan dalam persen (\%). Koefisien korelasi digunakan untuk mengatahui kontribusi atau peran variabel $X$ terhadap variabel $Y$.

3. Uji hipotesis Koefisien Korelasi dengan uji t Untuk mengetahui apakah koefisien penelitian signifikan atau tidak, maka perlu dilakukan uji koefisien korelasi.

4. Menentukan hipotesis statistik Dalam penelitian ini, hipotesis yang digunakan adalah sebagai berikut:

a. Ho $(\rho \leq 0)$ : Tidak terdapat hubungan yang positif antara efikasi diri dengan kinerja karyawan

b. Ha $(\rho>0)$ : Terdapat hubungan yang positif antara efikasi diri dengan kinerja karyawan.

Untuk melakukan pengujian dengan nilai $t_{\text {tabel, }}$ maka digunakan taraf nyata sebesar $5 \%$ atau 0,05 dan df $=n-2$, kemudian nilai $t_{\text {hitung }}$ dibandingkan dengan 


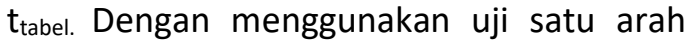
maka kriteria hasil pengujian adalah:

a. Terima Ho dan tolak Ha jika nilai $t_{\text {hitung }} \leq$ $t_{\text {tabel }}$ artinya, tidak terdapat hubungan positif antara efikasi diri dengan kinerja karyawan.

b. Tolak Ho dan Terima Ha jika nilai $t_{\text {hitung }}>$ $t_{\text {tabel }}$ artinya, terdapat hubungan positif antara efikasi diri dengan kinerja karyawan.

HASIL DAN PEMBAHASAN

Analisis Koefisien Korelasi Rank Spearman

Berikut akan dilakukan analisis koefisien korelasi untuk mengetahui keeratan hubungan antara variabel efikasi diri dengan kinerja karyawan PT Metraplasa dengan responden sebanyak 141 responden:

Tabel 5. Koefisien Korelasi Rank Spearman

\begin{tabular}{|c|c|c|c|}
\hline \multicolumn{4}{|c|}{ Correlations } \\
\hline & & $\begin{array}{c}\text { EFIKASI } \\
\text { DIRI }\end{array}$ & $\begin{array}{c}\text { KINERJA } \\
\text { KARYAWAN }\end{array}$ \\
\hline \multirow[t]{3}{*}{ EFIKASI DIRI } & $\begin{array}{l}\text { Correlation } \\
\text { Coefficient }\end{array}$ & 1,000 &, $537^{* *}$ \\
\hline & Sig. (1-tailed) & & ,000 \\
\hline & $N$ & 141 & 141 \\
\hline \multirow[t]{3}{*}{$\begin{array}{l}\text { KINERJA } \\
\text { KARYAWAN }\end{array}$} & $\begin{array}{l}\text { Correlation } \\
\text { Coefficient }\end{array}$ &, $537^{* *}$ & 1,000 \\
\hline & Sig. (1-tailed) & 000 & \\
\hline & $N$ & 141 & 141 \\
\hline Corre & ignificant at & $0.01 \mathrm{le}$ & I (1-tailed). \\
\hline
\end{tabular}

Output Correlations menjelaskan tentang nilai koefisien korelasi dan nilai signifikan antara variabel efikasi diri dengan kinerja karyawan, dapat diketahui dari korelasi antara variabel efikasi diri dengan kinerja karyawan di dapat nilai koefisien sebesar 0,537, hal ini menujukkan bahwa hubungan antara efikasi diri dengan kinerja karyawan adalah sedang.

\section{Analisis Koefisien Determinasi}

Untuk mengetahui seberapa besar kontribusi efikasi diri dengan kinerja karyawan, maka digunakan rumus koefisien determinasi sehingga dapat dilakukan perhitunngan sebagai berikut :

$K D=r_{s}^{2} \times 100 \%$

$K D=0,537^{2} \times 100 \%$

$K D=0,288 \times 100 \%$

$K D=28,8 \%$
Hasil dari analisis tersebut menunjukan bahwa kontribusi variabel efikasi diri terhadap variabel kinerja karyawan sebesar 28,8\% sedangkan sisanya sebesar $71,2 \%$ dipengaruhi oleh faktor lain diluar efikasi diri.

\section{Uji hipotesis Korelasi}

Untuk mengetahui apakah koefisien penelitian signifikan atau tidak, maka perlu dilakukan uji koefisien korelasi. Dalam penelitian ini uji signifikansi dilakukan dengan uji t, rumusnya:

1. Mencari $t_{\text {tabel }}$

Mencari $t_{\text {tabel }}$ dilakukan dengan signifikansi $5 \%$ atau 0,05 dan derajat bebas (df) $n-2$ atau $141-2=139$. Hasil yang diperoleh adalah 1,656

2. Mencari $t_{\text {hitung }}$

Untuk mencari berapa nilai $t_{\text {hitung }}$ maka digunakan rumus sebagai berikut:

$t=r \sqrt{\frac{n-2}{1-r^{2}}}$ 


$$
\begin{gathered}
t=0,573 \sqrt{\frac{141-2}{1-0,573^{2}}} \\
t=8,240
\end{gathered}
$$

Menentukan Hipotesis Statistik

Dalam penelitian ini, hipotesis yang digunakan adalah sebagai berikut:

Ho $(\rho \leq 0)$ : Tidak terdapat hubungan yang positif antara efikasi diri dengan kinerja karyawan

Ha $(\rho>0)$ : Terdapat hubungan yang positif antara efikasi diri dengan kinerja karyawan.

Diketahui nilai $t_{\text {hitung }}$ adalah sebesar 8,240 dan $t_{\text {tabel }}$ sebesar 1,656, maka $t_{\text {hitung }}>t_{\text {tabel }}(8,240>$ $1,656)$ artinya tolak Ho terima Ha. Jadi dapat disimpulkan bahwa terdapat hubungan antara efikasi diri (X) dengan kinerja karyawan (Y) pada PT Metraplasa.

\section{Pembahasan}

Berdasarkan analisis hasil penelitian yang dilakukan sebelumnya, selanjutnya akan dilakukan pembahasan hasil dari analisis atas hubungan efikasi diri dengan kinerja karyawan. Pada penelitian ini yang menjadi unit analisis adalah karyawan PT Metraplasa. Dengan menggunakan analisis korelasi diperoleh hasil bahwa terdapat hubungan yang signifikan antara efikasi diri dengan kinerja karyawan. Berikut ini penulis akan membahas hasil penelitian berdasarkan tujuan yang telah ditetapkan sebelumnya, yaitu:

1. Gambaran efikasi diri (self-efficacy) pada karyawan PT Metraplasa

Individu yang memiliki efikasi tinggi maka ia akan merasa yakin dan mampu dalam mengerjakan segala tugas dan mengatasi segala hambatan yang ada. Kepercayaan terhadap kemampuan diri, keyakinan terhadap keberhasilan yang selalu dicapai membuat seseorang bekerja lebih giat dan selalu menghasilkan yang terbaik.

Efikasi diri PT Metraplasa menurut pengukuran melalui kuesioner yang telah disebarkan menunjukan total skor rata-rata empirik sebesar 92.67 dan skor rata-rata teoritis 72 , skor rata-rata empirik lebih besar dibandingkan dengan skor rata-rata teoritis, dengan nilai 92.87 > 72 maka dapat diartikan bahwa rata-rata jawaban responden atas pernyataan pada instrumen variabel efikasi diri $(X)$ dapat dikatakan relatif baik. Self efficacy atau efikasi diri berkaitan dengan aspek objektif seseorang dalam organisasi yaitu kinerjanya.

Berikut ini adalah tanggapan responden mengenai efikasi diri pada PT Metraplasa adalah sebagai berikut:

Tabel 6. Tanggapan Responden mengenai Efikasi Diri Karyawan pada PT Metraplasa

\begin{tabular}{c|l|c}
\hline No. & \multicolumn{1}{|c}{ Indikator } & Total Skor \\
\hline 1 & $\begin{array}{l}\text { Yakin } \\
\text { menyelesaikan tugas } \\
\text { tertentu }\end{array}$ & 550,6 \\
\hline 2 & $\begin{array}{l}\text { Yakin dapat memotivasi } \\
\text { diri untuk melakukan } \\
\text { tindakan yang } \\
\text { diperlukan untuk } \\
\text { menyelesaikan tugas }\end{array}$ & 584,75 \\
\hline 3 & $\begin{array}{l}\text { Yakin bahwa diri mampu } \\
\text { berusaha dengan keras, } \\
\text { gigih, dan tekun }\end{array}$ & 541,4 \\
\hline 4 & $\begin{array}{l}\text { Yakin bahwa diri mampu } \\
\text { bertahan menghadapi } \\
\text { hambatan dan kesulitan }\end{array}$ & 523,8 \\
\hline 5 & $\begin{array}{l}\text { Yakin dapat } \\
\text { menyelesaikan } \\
\text { permasalahan } \\
\text { diberbagai situasi }\end{array}$ & 525,8 \\
\hline
\end{tabular}

Sumber: Data primer diolah 2018

Hasil perhitungan skor jawaban di atas menunjukkan bahwa tanggapan responden tertinggi berada pada indikator yakin dapat memotivasi diri untuk melakukan tindakan yang diperlukan untuk menyelesaikan tugas dengan jumlah skor rata- rata 584,75 dapat disimpulkan bahwa karyawan memiliki rasa yakin atas 
kemampuannya sehingga efikasi diri yang ada memberikan semangat dan dorongan motivasi diri untuk dapat melakukan atau menyelesaikan pekerjaannya dengan baik.

Sedangkan skor jawaban terendah berada pada indikator yakin dapat menyelesaikan tugas tertentu dengan jumlah skor rata-rata 550,6 dari hasil tersebut diketahui bahwa dalam penyelesaian tugas atau pekerjaan karyawan PT Metraplasa tidak terselesaikan dengan baik karena kurang yakinnya tiap individu dalam penyelesaian tugas baik secara kuantitas maupun kualitas pekerjaan yang dihasilkan.

2. Gambaran Kinerja karyawan PT Metraplasa

Kinerja Karyawan PT Metraplasa menurut pengukuran melalui kuesioner yang telah disebarkan menunjukan total skor rata-rata empirik sebesar 96.13 dan skor rata-rata teoritis sebesar 72 , skor ratarata empirik lebih besar dibandingkan dengan skor rata-rata teoritis, dengan nilai 96.13 > 72 maka dapat diartikan bahwa rata-rata jawaban responden atas pernyataan pada instrumen variabel kinerja karyawan $(\mathrm{Y})$ dapat dikatakan relatif baik.

Kinerja yang baik jika dilakukan maka akan menghasilkan suatu hasil yang memuaskan perusahaan dan karyawan itu sendiri, tetapi kinerja yang buruk akan membawa dampak yang sangat tidak baik bagi perusahaan, dapat menjatuhkan perusahaan dan menggulingkan perusahaan sehingga tujuan untuk kemajuan tidak bisa tercapai.

Berikut ini adalah tanggapan responden mengenai kinerja karyawan pada PT Metraplasa adalah sebagai berikut:
Tabel 7. Tanggapan Responden mengenai Kinerja Karyawan pada PT Metraplasa

\begin{tabular}{c|c|c}
\hline No. & Indikator & Total Skor \\
\hline 1 & Kualitas & 568,2 \\
\hline 2 & Kuantitas & 580,6 \\
\hline 3 & Ketepatan Waktu & 534,25 \\
\hline 4 & Efektivitas & 569 \\
\hline 5 & Kemandirian & 566,2 \\
\hline
\end{tabular}

Sumber: Data primer diolah 2018

Berdasarkan hasil perhitungan skor jawaban diatas maka diketahui bahwa tanggapan responden tertinggi berada pada indikator kuantitas dengan jumlah skor rata - rata 580,6 dapat disimpulkan bahwa karyawan memberikan hasil pekerjaan secara kuantitas yang baik sehingga meningkatkan kinerja karyawan tersebut.

Sedangkan skor jawaban terendah berada pada indikator ketepatan waktu dengan jumlah skor rata-rata 534,25 dari hasil tersebut diketahui bahwa dalam penyelesaian tugas atau pekerjaan karyawan PT Metraplasa yang dihasilkan tidak selalu tepat waktu, adanya keterlambatan atau penundaan pekerjaan yang dilakukan karyawan sehingga meyelesaikan pekerjaan diluar jam kerja dengan penyelesaian waktu pengerjaan yang lama. Hal inii yang dapat membuat kinerja karyawan menjadi menurun.

2. Hubungan efikasi diri (self-efflcacy) dengan kinerja Karyawan PT Metraplasa

Hasil pengolahan data yang dilakukan menggunakan korelasi rank spearman, dengan SPSS 23 menunjukkan bahwa variabel efikasi diri mempunyai hubungan secara signifikan terhadap kinerja karyawan, korelasi antara variabel efikasi diri dengan kinerja karyawan menunjukkan nilai sebsesar 0,573. Nilai koefisien determinasi (KD) menunujukkan persentase sebesar $28,8 \%$ dimana hasil tersebut menunjukan bahwa kontribusi variabel 
efikasi diri terhadap variabel kinerja karyawan sebesar $28,8 \%$ sedangkan sisanya sebesar $71,2 \%$ dipengaruhi oleh faktor lain diiluar efikasi diri. Diketahui nilai $t_{\text {hitung }}$ adalah sebesar 8,240 dan $t_{\text {tabel }}$ sebesar 1,656 , maka $t_{\text {hitung }}>t_{\text {tabel }}(8,240>1,656)$ artinya tolak Ho terima Ha. Jadi dapat disimpulkan bahwa terdapat hubungan antara efikasi diri $(X)$ dengan kinerja karyawan (Y) pada PT Metraplasa.

Hasil penelitian ini ikut menguatkan hasil penelitian dilakukan oleh oleh Ika Sulistiowati tahun 2014 dengan judul Hubungan antara Self Efficacy Dengan Kinerja Petugas Kebersihan Rumah Sakit Di Kota Madiun. Penelitian ini bertujuan untuk mengetahui hubungan antara self efficacy dengan kinerja petugas kebersihan rumah sakit, perbedaan kinerja petugas kebersihan rumah sakit berdasarkan kompensasi finansial, dan hubungan antara self efficacy dan kompensasi finansial dengan kinerja petugas kebersihan rumah sakit. Metode pengumpulan data menggunakan skala self efficacy, skala kinerja petugas kebersihan dan angket kompensasi. Subjek penelitian ini berjumlah 50 orang petugas kebersihan rumah sakit di kota Madiun yang berstatus outsourcing dengan masa kerja minimal selama 3 bulan. Data penelitian dianalisis menggunakan analisis regresi dan anova satu jalur. Hasil penelitian menunjukkan bahwa ada hubungan positif dan signifikan antara self-efficacy dengan kinerja petugas kebersihan $r=0.624$, tidak ada perbedaan kinerja petugas kebersihan berdasarkan kompensasi finansial $\mathrm{F}=0.002 ; \mathrm{p}>0.005$, dan ada huungan yang positif dan signifikan antara self efficacy dan kompensasi finansial dengan kinerja petugas kebersihan $r=$ 0.639. $R^{2}=0.409$. Hal ini menunjukkan bahwa kinerja petugas kebersihan dipengaruhi oleh self-efficacy dan kompensasi finansial sebesar $40.9 \%$ sedangkan sisanya $59.1 \%$ dipengaruhi oleh faktor-faktor lain yang tidak diteliti dalam penelitian ini.
Hasil penelitian menunjukkan bahwa efikasi diri yang dimiliki oleh karyawan PT Metraplasa memiliki hubungan yang positif dan signifikan dengan kinerja karyawan, dengan demikian hipotesis yang telah diajukan dapatlah dikatakan terbukti, bahwa variabel Efikasi diri (X) memiliki hubungan dengan kinerja karyawan $(Y)$, maka hipotesis dalam penelitian ini dapat diterima.

\section{Interpretasi Hasil Penelitian}

Berdasarkan hasil penelitian yang dilakukan pada PT Metraplasa dengan menggunakan responden sebanyak 141 orang tentang hubungan efikasi diri dengan kinerja karyawan mendapatkan hasil bahwa efikasi diri karyawan PT Metraplasa relatif baik begitupula dengan kinerja karyawan PT Metraplasa sudah relatif baik. Berdasarkan perhitungan korelasi antara efikasi diri terhadap kinerja karyawan, diperoleh koefisien korelasi sebesar 0,573, $r=$ $0,573>0$ artinya hal ini menunjukkan adanya hubungan yang sedang antara efikasi diri dengan kinerja karyawan pada PT Metraplasa. Dari Hasil uji hipotesis diperoleh $t_{\text {hitung }}>t_{\text {tabel }}$ yaitu dengan nilai 8,240 $>1,656$ yang berarti $H_{\circ}$ ditolak dan $\mathrm{H}_{\mathrm{a}}$ diterima.

Individu cenderung berkonsentrasi dalam tugas-tugas yang mereka rasakan mampu dan percaya dapat menyelesaikannya serta menghindari tugas-tugas yang tidak dapat mereka kerjakan. Keyakinan akan kemampuan yang dimiliki oleh tiap individu ini akan mencapai hasil pekerjaan atau kinerja yang baik ditunjukan dengan kuantitas dan kualitasnya. Dan Sebaliknya, Apabila Efikasi diri yang dimiliki cenderung rendah maka akan mengakibatkan ketidakberhasilan dalam melaksanakan atau menyelesaikan pekerjaan yang diberikan kepadanya. Dengan efikasi diri atau self-efficacy yang kuat diindikasi akan membuat kinerja karyawan meningkat dengan memberikan hasil kerja yang memuaskan dan membantu dalam pencapaian tujuan organisasi atau perusahaan yang diinginkan. 
Maka hasil dari penelitian ini dapat diinterpretasikan bahwa terdapat hubungan nyata yang signifikan antara efikasi diri dengan kinerja karyawan. Artinya, semakin tinggi efikasi diri yang dimiliki oleh karyawan maka semakin tinggi pula tingkat kinerja karyawan yang ada dalam perusahaan.

\section{PENUTUP}

Simpulan

Berdasarkan hasil penelitian yang telah dilakukan dapat diseimpulkan bahwa terdapat hubungan positif dan signifikan antara efikasi diri dengan kinerja karyawan. Bahwa karyawan yang memiliki efikisasi diri memiliki kinerja yang lebih baik. Karyawan yang memiliki keyakinan bahwa ia dapat menyelesaikan tugas tertentu, yakin dapat memotivasi diri untuk melakukan tindakan yang diperlukan untuk menyelesaikan tugas, yakin bahwa diri mampu berusaha dengan keras, gigih dan tekun, yakin bahwa diri mampu bertahan menghadapi hambatan dan kesulitan, yakin dapat menyelesaikan permasalahan diberbagai situasi akan memiliki tingkat kinerja yang lebih baik secara kualitas, kuantitas, ketepatan waktu, efektivitas, kemandirian.

\section{Saran untuk PT Metraplasa}

Setelah mengamati dan menganalisa hasil penelitian, penulis menyarankan beberapa hal yang diharapkan dapat berguna sebagai masukan dan pertimbangan bagi PT Metraplasa, maka penulis mengajukan beberapa saran sebagai berikut :

1. Saran Untuk meningkatkan kinerja

Meningkatkan kinerja dengancara menetapkan standar kualitas dan kuantitas hasil kerja yang disosialisasikan kepada seluruh karyawan, mengurangi tingkat ketidakhadiran dengan menetapkan kompensasi kehadiran dan punishment bagi ketidakhadiran.

2. Saran untuk meningkatkan Efikasi Diri Meningkatkan efikasi diri dengan cara mengubah kebiasaan diri yang diyakini dapat memicu kurangnya atau rendahnya efikasi diri dalam diri seseorang, hal ini dapat diperoleh melalui sumber efikasi diri yaitu pengalaman menguasai sesuatu prestasi (performance accomplishment), pengalaman vikarius (vicarious experience), persuasi sosial (persuasi sosial), dan pembangkitan emosi (Emotional / physiological states). Perusahaan sebaiknya melakukan pengadaan program peningkatan efikasi diri karyawan dengan sering dilakukannya training and motivation kepada karyawan sehingga diharapkan kegiatan tersebut akan menambah kecakapan dan keterampilan karyawan dalam bekerja.

\section{Saran untuk Peneliti Selanjutnya}

Penelitian mengenai hubungan efikasi diri dengan kinerja karyawan ini dapat diteliti lebih lanjut untuk memperoleh hasil yang lebih baik, bagi pihak - pihak yang tertarik untuk meneliti topik ini secara lebih mendalam, penulis memberikan saran sebagai berikut :

1. Untuk penelitian selanjutnya dapat mempeluas ruang lingkup penelitian mengenai efikasi diri dan kinerja karyawan.

2. Untuk penelitian selanjutnya dapat memperkaya indikator masing - masing variabel.

3. Untuk penelitian Selanjutnya dilakukan secara kualitatif dengan wawancara.

\section{REFERENSI}

Alwisol. (2009). Psikologi Kepribadian. Edisi Revisi. Malang: Penerbit UMM Press.

Bandura, A. (1997). Self-efficacy. In V. S. Ramachaudran (Ed.), Encyclopedia of human behavior (Vol. 4, pp. 71-81). New York: Academic Press. (Reprinted in $\mathrm{H}$. Friedman [Ed.], Encyclopedia of mental health. San Diego: Academic Press.

Bandura. (1997). Self Efficacy: The Exercise of Control. New York: Freeman

Dessler, G. (2015). Manajemen Sumber Daya Manusia. Jakarta: Salemba Empat 
Nancy Yusnita: Analisis Hubungan Efikasi...

Febriantin. (2012). Hubungan Antara Efikasi Diri dan Pengambilan Keputusan Dengan Kinerja (Studi pada SDN Kecamatan Duren Sawit Jakarta Timur). Jurnal Manajemen Pendidikan. LBPP Lia Pramuka.

Ghufron, M. Nur dan Rini Risnawita S. (2010). Teori-teori Psikologi. Yogyakarta: Ar-Ruzz Media.

Handoko, H. (2010). Manajemen Personalia dan Sumber Daya Manusia. Yogyakarta: Penerbit BPFE.

Hasibuan, M. (2014). Manajemen Sumber Daya Manusia. Jakarta: PT Bumi Aksara

Istijanto. (2006). Riset Sumber Daya Manusia Cara Praktis Mendeteksi Dimensi Dimensi Kerja Karyawan. Cetakan Kedua. Jakarta, PT SUN Jakarta.

Lauster, P. 2005). Tes Keperibadian (Terjemahan : D.H. Gulo). Jakarta: PT Bumi Aksara

Luthans, F. (2014). Perilaku Organisasi Edisi Bahasa Indonesia. Yogyakarta: PT Andi Offset.

Manara. (2008). Pengaruh Self Efficacy terhadap Resiliansi pada Mahasiswa Universitas Islam Negeri UIN. Malang: Malang

Mangkunegara, Anwar P. (2007). Manajemen Sumber Daya Manusia Perusahaan. Bandung: PT Remaja Rosdakarya.

Moehariono. (2009). Pengukuran kinerja berbasis kompetensi. Bandung. Ghalia Indah.

Rachmawati, Ike K. (2008). Manajemen Sumber Daya Manusia. Yogyakarta: CV Andi Offset.

Rizki, D. (2016). Pengaruh Self Efficacy Terhadap Kinerja Karyawan Dengan Motivasi Sebagai Variabel Intervening (Studi Pada Karyawan Divisi Finance Dan Divisi Human Resource PT. Coca-Cola Distribution Indonesia, Surabaya).Jurnal IImu Manajemen Volume 4 Nomor 3 Jurusan Manajemen Fakultas Ekonomi Universitas Negeri Surabaya
Riniwati, H. (2011). Mendongkrak Motivasi dan Kinerja, Pendekatan Pemberdayaan SDM. Malang: UB Press.

Robbins \& Judge. (2015). Organizational Behavior, 16th Editions. London: Pearson Education Ltd.

Santoso, Robi J. (2012). Hubungan Antara Self Efficacy Dengan Kinerja Pada Karyawan Di PT Timatex. Salatiga: Universitas Muhammadiyah Surakarta.

Sedarmayanti. (2009). Sumber Daya Manusia dan Produktivitas Kerja. Bandung,

Penerbit Mandar Maju.

Sugiyono. (2012). Metode Penelitian Bisnis (Pendekatan kuantitatif, kualitatif, dan R \& D). Bandung: Alfabeta.

Sulistiyani, Ambar T. dan Rosidah. (2009). Manajemen Sumber Daya Manusia; Konsep, Teori, Dan Pengembangan dalam Konteks Organisasi Publik. Edisi Kedua. Yogyakarta: Penerbit Graha Ilmu.

Sulistiowati, I. (2014). Hubungan Antara Self Efficacy Dengan Kinerja Petugas Kebersihan Rumah Sakit Di Kota Madiun, Universitas Katolik Widya Mandala Madiun.

Wahyu, P. dan Ratnaningtyas, D. (2012). Pengaruh Self Efficacy Dan Kecerdasan Emosi Terhadap Motivasi Berprestasi Siswa SMK PGRI 1. Madiun: IKIP PGRI Madiun.

Yani, M. (2012). Manajemen Sumber Daya Manusia. Jakarta: Penerbit Mitra Wacana Media. 